\title{
Faktor Risiko Kesehatan Lingkungan Di Sekolah Dasar Kabupaten Padang Pariaman
}

\section{Environmental Health Risk Factors in Primary Schools Padang Pariaman Regency}

\author{
Miladil Fitra ${ }^{\mathrm{a}}$, Awaluddin ${ }^{\mathrm{b}}$, Alsri Windra Doni ${ }^{\mathrm{c}}$, Dismo Katiandagho ${ }^{\mathrm{d}}$. \\ ${ }^{a, b, c}$ Politeknik Kesehatan Kemenkes Padang, Indonesiad \\ ${ }^{c}$ Jurusan Kesehatan Lingkungan Poltekkes Kemenkes Manado, Indonesia \\ JL.Simpang Pondok Kopi Nanggalo, 25146, Kota Padang
}

\section{A B S T R A C T/ A B S T R A K}

\begin{abstract}
School conditions that do not meet environmental health requirements are a threat to students and school members to be affected by health problems and infectious diseases. The purpose of this study was to analyze risk factors for environmental health at SDN 13 Batang Gasan and the potential health problems that would arise. This research is descriptive, with the population is the facilities and infrastructure and all students of SD Negeri 13 Batang Gasan, totaling 82 people. Data analysis was performed using environmental health risk factor analysis, namely providing answers about the risks that will arise, by dividing 6 risk criteria, namely very high (> 80\%), high (60\%-79\%), moderate (40\%-59\%), low (20\%-39\%), very low (1\%-19\%) and safe / not risky (0\%). The results of the study prove that the level of environmental health risk in Public Elementary School 13 is high (65\%). It is suggested that schools need to make efforts to control risk factors.
\end{abstract}

Keywords: Environmental Health Risk Factors

\begin{abstract}
Kondisi sekolah yang tidak memenuhi persyaratan kesehatan lingkungan merupakan ancaman bagi peserta didik dan warga sekolah untuk terkena gangguan kesehatan dan penyakit menular. Tujuan penelitian ini untuk menganalisis faktor risiko kesehatan lingkungan di SDN 13 Batang Gasan dan potensi gangguan kesehatan yang akan timbul. Penelitian ini bersifat deskriptif, dengan populasi adalah sarana dan prasarana serta semua siswa SDN 13 Batang Gasan. Analisis data dilakukan dengan menggunakan analisis faktor risiko kesehatan lingkungan yaitu memberikan jawaban tentang risiko yang akan timbul, dengan membagi 6 kriteria risiko yaitu sangat tinggi (>80\%), Tinggi (60\%-79\%), sedang (40\%-59\%), rendah (20\%-39\%), sangat rendah (1\%-19\%) dan aman/tidak berisiko (0\%). Hasil penelitian membuktikan bahwa tingkat risiko kesehatan lingkungan di SD N 13 dengan kategori tinggi (65\%). Disarnakan agar pihak sekolah perlu melakukan upaya pengendalian faktor risiko.
\end{abstract}

Kata Kunci : Faktor Risiko Kesehatan Lingkungan

email : miladilfitra@gmail.com

\section{PENDAHULUAN}

Faktor risiko kesehatan lingkungan adalah kekuatan bahan, zat, benda, atau perilaku hewan maupun manusia yang dapat memiliki potensi menyebabkan atau memperberat timbulnya gangguan kesehatan pada penduduk ${ }^{1}$
Sekolah merupakan tempat berkumpulnya peserta didik dan warga, sekolah dalam kegiatan proses belajar mengajar, dengan demikian kondisi bangunan sekolah yang tidak sehat dapat berpengaruh terhadap kesehatan peserta didik maupun warga sekolah.

Tersedianya sarana dan prasarana yang memadai di sekolah, baik kualitas maupun kuantitas harus diupayakan secara terus menerus termasuk perawatan dan 
pemeliharaannya dengan melibatkan semua potensi yang ada di lingkungan sekolah. Lingkungan sekolah yang sehat sangat diperlukan, selain dapat mendukung proses pembelajaran diharapkan juga dapat membudayakan perilaku hidup bersih dan sehat, tidak hanya pada peserta didik, tetapi diharapkan dapat meluas pada keluarga dan masyarakat sekitar ${ }^{2}$

Hasil survey terhadap bahaya dan risiko kesehatan di gedung sekolah pada tahun 2004 yang dilaksanakan oleh Direktorat Penyehatan Lingkungan bekerja sama dengan FKM-UI di Kabupaten Semarang, Kab.Gresik, Kab. Bantul, DKI Jakarta mengindikasikan bahwa risiko kesehatan pada umumnya disebabkan oleh aspek kualitas udara ruang (ventilasi kurang baik) dapat menyebabkan proses pertukaran udara tidak lancar sehingga menjadi pengap dan lembab yang dapat mengakibatkan berkembang biaknya bakteri, virus, dan jamur yang berpotensi menyebarkan penyakit seperti ISPA, secara langsung menimbulkan kelelahan dan ketidaknyamanan dalam belajar, dan aspek sanitasi (toilet yang tidak bersih berpotensi menularkan penyakit yang bersumber dari tinja manusia seperti diare, cacingan, hepatitis A, kurangnya ketersediaan air bersih berpotensi menimbulkan penyakit seperti: Diare, kholera, disentri, hepatitis, penyakit kulit dan penyakit mata, pengelolaan limbah yang kurang memadai dapat menimbulkan bau, mengganggu estetika dan menjadi tempat perindukan nyamuk dan bersarangnya tikus, kondisi ini berpotensi menyebar dan menularkan penyakit leptospirosis dan Filariasis (kaki gajah) khusus didaerah endemis Filariasis dan PSN yang tidak baikdapat berpotensi menimbulkan penyakit $\mathrm{DBD}^{3}$

Kondisi sekolah yang tidak memenuhi persyaratan kesehatan lingkungan merupakan ancaman bagi peserta didik dan warga sekolah untuk terkena gangguan kesehatan dan penyakit menular (penyakit menular tersebut antara lain Demam Berdarah, Cacingan, TBC, Diare, dsb.) merupakan penyakit berbasis lingkungan, oleh sebab itu perlu dilakukan kajian Faktor Risiko Kesehatan Lingkungan di Sekolah. Hal ini juga di dukung oleh laporan Dinas Kesehatan Kabupaten Padang Pariaman dimana penyakit yang paling banyak di Kabupatn Padang Pariaman tahun 2016 adalah ISPA (51127 kasus), diikuti Gastritis(16574 kasus) dan Penyakit kulit Infeksi (10745 kasus) ${ }^{3}$ dan hasil survey awal serta wawancara dengan Kepala Bidang Perencanaan dan pengembangan Pendidikan dan Kebudayaan Dinas pendidikan Kabupaten Padang Pariaman menyatakan Sekolah dasar yang paling minim sarana dan Prasarana Sanitasi adalah SDN 13 Batang Gasan Kab.Padang Pariaman serta kondisi sanitasi di SDN 13 Batang Kasan masih rendah ${ }^{4}$. Penyakit berbasis lingkungan adalah penyakit yang penyebaran dan penularannya dipengaruhi oleh faktor lingkungan ${ }^{9}$

Dari hal tersebut diatas peneliti ingin melakukan penelitian analisis faktor risiko kesehatan lingkungan SDN 13 Batang Gasan Kab.Padang Pariaman dan potensi gangguan kesehatan yang timbul. Adapun tujuan dari penelitian ini adalah Diketahuinya Tingkat Risiko Kesehatan Lingkungan dan gangguan kesehatan yang akan timbul akibat faktor risiko kesehatan lingkungan di SD N 13 Batang Gasan Kabupaten Padang Pariaman.

\section{METODE}

Disain penelitian yang digunakan dalam penelitian ini adalah deskriptif dengan menggambarkan faktor risiko kesehatan lingkungan. Populasi dalam penelitian ini yaitu sarana yangdan siswa di SDN 13 Gasan yang berjumlah 82 orang. Instrument yang dugunakan dalam penelitian ini yaitu menggunakan lembar observasi dan kuesioner tentang faktor risiko yang akan timbul, dengan membagi 6 kriteria Risiko yaitu sangat tinggi (>80\%), Tinggi (60\%-79\%), sedang (40\%-59\%), rendah (20\%-39\%), sangat rendah (1\%-19\%) dan aman/tidak berisiko (0\%). Data hasil penelitian dianalisis secara deskriptif

\section{HASIL}

Faktor risiko kesehatan lingkungan yang ada disekolah dapat berpengaruh terhadap proses pembelajaran maupun kesehatan warga sekolah. Kondisi dari komponen atau bagian-bagian bangunan serta fasilitas pendukung sekolah dalam keadaan tertentu dapat menyebabkan timbulnya masalah kesehatan.

Untuk Hasil faktor risiko kesehatan lingkungan di SDN 13 Gasan dapat dilihat pada tabel dibawah ini: 
Tabel 1. Faktor Risiko Kesetan Lingkungan di SDN 13 Batang Gasan

\begin{tabular}{|c|c|c|}
\hline No & Memenuhi Syarat & Tidak memenuhi Syarat \\
\hline 1 & Dinding & 1. Atap dan talang \\
\hline 2 & Pencahayaan Ruang Kelas & 2. Lantai \\
\hline 3 & Pencahayaan Ruang Pustaka & 3. Jarak Papan Tulis dengan Murid terdepan $<2,5 \mathrm{~m}$ \\
\hline 4 & Ventilasi Ruang Kelas & 4. Sarana Cuci Tangan tidak ada \\
\hline 5 & Kepadatan Ruangan & 5. Air Bersih \\
\hline 6 & $\begin{array}{l}\text { Jarak papan tulis dengan murid paling } \\
\text { belakang }<9 \text { meter }\end{array}$ & 6. Kamar Mandi \\
\hline 7 & Kebisingan & $\begin{array}{l}\text { 7. WC dan Urinior } \\
\text { 8. Tempat Sampah } \\
\text { 9. Saluran Pembuangan Air Limbah (SPAL) } \\
\text { 10. Vektor } \\
\text { 11. Halaman Sekolah } \\
\text { 12. Meja Belajar Peserta Didik } \\
\text { 13. Prilaku (Kuku Panjang) }\end{array}$ \\
\hline
\end{tabular}

Dari tabel 1 didapat 13 item atau $65 \%$ faktor risiko tidak memenuhi syarat (Berpotensi menimbulkan gangguan kesehatan) yang dikategorikan risiko tinggi.

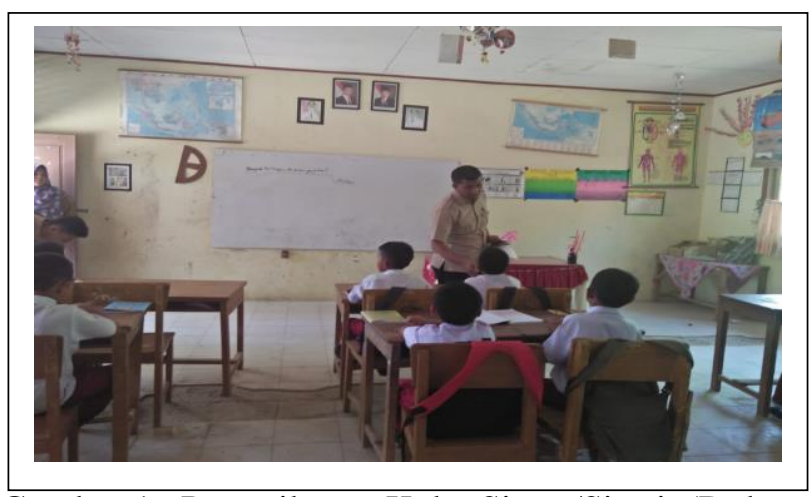

Gambar 1 . Pemeriksaan Kuku Siswa/Siswi. (Dokumen Pribadi)

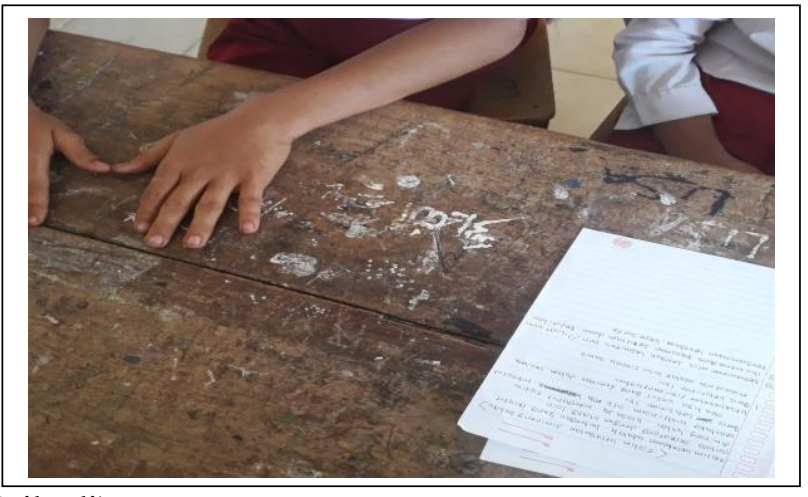

tidak menggenang dibawah dan dibuat Saluran Pembuangan Air hujan.

\section{Kondisi Dinding}

Dinding bersih, kuat, tidak retak, tidak pecah, permukaan yang selalu kontak dengan air kedap air serta permukaan bagian dalam mudah dibersihkan dan terang oleh sebab itu dinding dikategorikan memenuhi syarat oleh sebab itu tidak perlu dilakukan pengendalian faktor risiko.

\section{Kondisi Lantai}

Lantai kedap air, tidak licin tetapi ada beberapa lantai keramik yang pecah/ tidak rata sehingga lantai menjadi tidak bersih dan berdebu oleh sebab itu dapat mengurangi kenyamanan dan estetika serta kondisi ini bisa 
mengakibatkan berkembang biaknya bakteri, virus dan jamur yang dapat meningkatkan risiko penuran penyakit ISPA, campak dan cacar air ${ }^{5}$, untuk itu perlu dilakukan kegiatan pengelolaan faktor risiko dengan cara memperbaiki lantai keramik yang pecah dan membersihkan lantai minimal sehari sekali dengan menggunakan larutan desinfektan serta pembersihan lantai harus menggunakan kain pel basah atau facum cleanner untuk menghilangkan debu

\section{Pencahayaan Ruang Kelas}

Pencahayaan ruang kelas cukup terang ditandai dengan dapat membaca buku dengan jelas tanpa bantuan lampu/penerangan pada siang hari oleh sebab itu pencahayaan ruang perpustakaan dikategorikan memenuhi syarat oleh sebab itu tidak perlu dilakukan pengendalian faktor risiko

\section{Pencahayaan Ruang Perpustakaan}

Pencahayaan ruang perpustakaan cukup terang ditandai dengan dapat membaca buku dengan jelas tanpa bantuan lampu/penerangan pada siang hari oleh sebab itu pencahayaan ruang perpustakaan dikategorikan memenuhi syarat oleh sebab itu tidak perlu dilakukan pengendalian faktor risiko

\section{Ventilasi}

Ventilasi pada semua kelas (100\%) mempunyai luas ventilasi $>20 \%$ luas lantai dan semua kelas tidak menggunakan AC oleh sebab itu Ventilasi kelas dikategorikan memenuhi syarat dan tidak perlu dilakukan pengendalian faktor risiko

\section{Kepadatan Ruangan Kelas}

Setiap peserta didik di SDN 13 Gasan mendapat ruangan lebih dari $1,75 \mathrm{M}^{2}$ berarti Kepadatan ruang kelas dikategorikan memenuhi syarat oleh sebab itu tidak perlu dilakukan pengendalian faktor risiko.

\section{Jarak Papan Tulis dengan murid terdepan}

Hasil penelitian membuktikan bahwa dari 6 ruang kelas, ada 2 kelas Jarak Papan Tulis dengan murid terdepan kurang dari 2,5 Meter yaitu kelas 4 (2,4 m) dan kelas 5 (2,3 m) hal ini dapat mengakibatkan debu kapur atau spidol beterbangan dan terhirup ketika menghapus papan tulis, sehingga untuk jangka lama akan berpengaruh terhadap fungsi paru, oleh sebab itu perlu pengendalian faktor risiko dengan cara menggeser kursi dan meja murid terdepan sejauh $>2,5$ meter. $^{6}$

\section{Jarak Papan Tulis dengan murid paling belakang}

Hasil penelitian membuktikan bahwa dari 6 ruang kelas didapat semua ruangan memiliki Jarak Papan Tulis dengan murid paling belakang kurang dari 9 meter oleh sebab itu tidak perlu dilakukan pengendalian faktor risiko

\section{Sarana Cuci Tangan}

Sarana Cuci Tangan di 6 kelas tidak ada satupun yang tersedia, oleh sebab itu pihak sekolah harus merencanakan dan menyediakan sarana cuci tangan minimal tersedia 1 tempat cuci tangan untuk 2 kelas, sabun dan air bersih yang mengalir.

Tangan yang kotor berpotensi menularkan penyakit. Kebiasaan cuci tangan dengan sabun mampu menurunkan kejadian penyakit diare, dan cacingan. Tersedianya tempat cuci tangan yang dilengkapi dengan sabun bertujuan untuk menjaga kebersihan diri dan melatih kebiasaan cuci tangan dengan menggunakan sabun sebelum makan dan sesudah buang air besar serta setelah melakukan kegiatan yang menyebabkan tangan menjadi kotor. ${ }^{3}$

\section{Kebisingan}

Hasil wawancara dengan responden tidak satupun peserta didik yang mengeluhkan kebisingan oleh sebab itu kebisingan dikategorikan memenuhi syarat dan tidak diperlukan pengendalian risiko

\section{Air Bersih}

Hasil pengamatan dan wawancara dengan penjaga sekolah air bersih di SDN 13 Gasan kurang mencukupi bagi warga sekolah ini dikarenakan sumber air bersih berasal dari tadah hujan serta air yang kurang jernih.

Ketersediaan air bersih baik secara kuantitas dan kualitas mutlak diperlukan untuk menjaga kebersihan perorangan dan lingkungan. Beberapa penyakit yang dapat ditularkan melalui air antara lain: Diare, kholera, disentri, hepatitis, penyakit kulit, penyakit mata, oleh sebab itu pihak sekolah harus merencanakan dan membuat sumur gali/ bor minimal air bersih mencukupi kebutuhan sekolah yaitu 15 liter/orang/hari, jernih, tidak berwarna, tidak berasa dan tidak berbau serta memenuhi persyaratan kualitas bakteriologis oleh sebab itu pada saat membangun Sarana Air Bersih (SAB) harus memperhatikan hal-hal yang bisa mempengaruhi kualitas air bersih 
(seperti: jarak SAB dengan Septic tank minimal 10 meter). Bila terjadi keretakan pada lantai sumur, dinding sumur dan saluran pembuangannya segera dilakukan perbaikan agar tidak tercemar. ${ }^{7}$

Kualitas air bersih mengacu pada Peraturan Menteri Kesehatan RI Nomor 32 tahun 2017 tentang Standar Baku Mutu Kesehatan Lingkungan dan Persyaratan Kesehatan Air untuk Keperluan Higiene sanitasi, Kolam Renang. Solus Per Aqua dan Pemendian Umum.

\section{Kamar Mandi}

Hasil pengamatan pada Kamar Mandi dekat ruangan guru didapat ventilasi yang kurang dari $20 \%$ luas lantai dan pencahayaan yang kurang, terlihat ada genangan air dilantai serta ada jentik di bak mandi. Hal ini nantinya dapat menjadi tempat perkembang biakan nyamuk, demikian juga kamar mandi yang pencahayaannya kurang memenuhi syarat menjadi tempat peristirahatan nyamuk sehingga berpotensi menularkan penyakit melalui gigitan nyamuk seperti DBD/ Malaria/ Kaki gajah ${ }^{5}$ oleh sebab itu perlu dilakukan pengendalian faktor risiko degan cara melakukan pengurasan bak mandi minimal 1 kali dalam seminggu, bila bak mandi tidak akan digunakan dalam jangka waktu lama(misalnya pada saat liburan panjang), maka bak mandi harus dikosongkan serta menyediakan penerangan lampu di bak mandi

\section{WC dan Urinior}

WC dan Urinior tidak ada disediakan untuk Siswa di SDN 13 Gasan, yang ada disediakan hanya untuk guru dan kepala sekolah hal ini menyebabkan siswa buang air kecil maupun buang air besar disembarangan.

Tinja (faeces) dan urine merupakan sumber penularan penyaki perut (seperti Diare dan cacingan), hepatitis A. Penyakit-penyakit ini dapat ditularkan melalui air, tangan, makanan dan lalat, selain itu juga mengakibatkan gangguan estetika ${ }^{3}$. Tinja dan urine harus dilokalisir / ditampung dalarn septic tank, agar tidak mencemari sumber air tanah (sumur) dan tanah di sekolah. WC dan urinoir yang tidak memenuhi syarat kesehatan berpotensi menularkan dan menyebarkan penyakit tersebut diatas.

Pihak sekolah perlu menyediakan WC dan Urinior minimal $1 \mathrm{wc}$ untuk 40 siswa dan $2 \mathrm{wc}$ untuk siswi karna berdasarkan Kepmenkes nomor 1429 tahun 2006 menyatakan setiap sekolah minimal menyediakan $1 \mathrm{WC}$ untuk 40 siswa dan $1 \mathrm{WC}$ untuk 25 siswi (WC siswa dan siswi harus terpisah)

\section{Sampah}

Di SDN 13 Gasan terdapat 8 ruangan, dari 8 ruangan hanya 6 ruangan yang disediakan tempat sampah sedangkan 2 ruangan lagi tidak tersedia tempat sampah yaitu ruangan kelas 5 dan ruangan pustaka (hanya $75 \%$ terpenuhi) dan tidak adanya Tempat pembuangan sampah sementara (TPS), hal ini dapat menjadi tempat berkembang biaknya vektor penyakit, seperti lalat, nyamuk, tikus dan kecoa. Selain itu dapat juga menyebabkan pencemaran tanah dan menimbulkan gangguan kenyamanan dan estetika $^{5}$ oleh sebab itu hendaknya pihak sekolah harus menyediakan tempat sampah tiap ruangan dan merencanakan dan mengaplikasikan membuat Tempat Pembuangan sampah sementara sehingga tempat berkembang biaknya vektor penyakit dapat dikendalikan

16. Saluran Pembuangan Air Limbah (SPAL)

Hasil pengamatan masih terlihat ada genangan air dekat Saluran Pembuangan Air Limbah dan tidak ada aliran air kesaluran umum / selokan.

Sarana Pembuangan air limbah yang tidak memenuhi syarat dan tidak terpelihara akan menimbulkan bau, mengganggu estetika dan menjadi tempat perindukan nyamuk dan bersarangnya tikus yang berpotensi menyebarkan dan menularkan penyakit leptospirosis dan filariasis ${ }^{3}$ oleh sebab itu perlu dilakukan pengendalian dengan cara memperbaiki saluran pembuangan air limbah.

\section{Vektor}

Hasil pengamatan masih terlihat ada lalat, jentik nyamuk di SDN 13 Gasan serta wawancara dengan petugas sekolah kadangkadang ada tikus terlihat disiang hari oleh sebab itu perlu dilakukan pengendalian faktor risiko sebagai berikut:

1) Tikus merupakan vektor penyakit pes, Leptospirosis dll, selain sebagai vektor penyakit, tikus juga dapat merusak bangunan dan instalasi listrik. Hal ini akan meningkatkan risiko penularan penyakit tersebut diatas juga berisiko menimbulkan terjadinya arus pondek pada aliran Iistrik yang dapat menimbulkan kebakaran ${ }^{5}$ oleh sebab itu perlu dilakukan pengendalian 
dengan cara memasang perangkap tikus dan membersihkan sampah berserakan

2) Nyamuk Merupakan vektor penyakit, jenis nyamuk tertentu menularkan penyakit yang berbeda. Nyamuk Aedes Aegypti dapat menyebabkan penyakit Demam Berdarah. Anak-anak usia sekolah merupakan kelompok risiko tinggi terjangkit penyakit Demam Berdarah. Nyamuk demam berdarah, senang berkembang biak pada tempat-tempat penampungan air maupun non penampungan air. Beberapa tempat perindukan yang harus diwaspadai antara lain: bak air, saluran air, talang, vas bunga, barang-barang bekas, air buangan dispenser, kulkas, dsb. Penyakit lain yang ditularkan oleh nyamuk adalah malaria, fllariasis (Direktorat Jenderal PP dan PL Kemenkes RI, 2014) oleh sebab itu perlu dilakukan pengendalian dengan cara pemberantasan sarang nyamuk (PSN) dan apabila ada siswa positif DBD wajib untuk dilakukan Fogging.

3) Keberadaan lalat menunjukan bahwa lingkungan sekolah tidak bersih dan mengganggu estetika. Lalat berkembang biak ditimbunan sampah yang membusuk. Secara mekanis lalat menyebarkan penyakit yang disebabkan oleh bakteri pathogen seperti diare, disentri, typoid dan penyakit gastroenteritis lainnya ${ }^{5}$

Tikus, Nyamuk dan lalat merupakan vektor penyakit yang dapat menyebabkan Leptospirosis, DBD dan diare, oleh sebab itu perlu pengendalian faktor risiko dilakukan dengan cara: melakukan kerja bakti/ goro $1 \mathrm{kali}$ seminggu membersihkan sampah yang berserakan, menguras bak mandi atau tempat penampungan air 1 kali seminggu dan melakukan pengamatan jentik secara teratur disetiap sarana penempungan air atau wadah yang berpotensi adanya jentik Aedes minimal 1 kali seminggu serta memasang perangkap tikus.

\section{Kondisi Halaman Sekolah}

Hasil pengamatan masih terlihat ada sampah yang berserakan dihalaman sekolah dan berdebu. Halaman sekolah berdebu pada musim kemarau akan menyebabkan debu beterbangan sehingga berpotensi menirnbulkan penyakit ISPA. Dan pada musim hujan halaman menjadi becek dan berpotensi

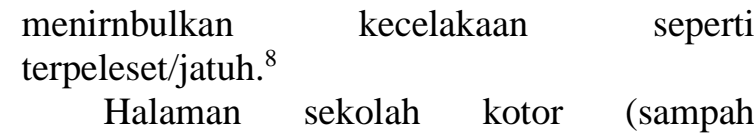
berserakan), dapat mengganggu estetika dan menjadi tempat berkembang biaknya nyamuk, tikus, lalat sehingga berpotensi menyebarkan penularan penyakit : DBD, Leptospirosis dan Diare. Halaman sekolah yang ada genangan air akan menjadi tempat berkembang biaknya nyamuk sehingga berpotensi menyebarkan penularan penyakit: Malaria, Filaria, Leptospirosis.Tanaman/tumbuhan yang tidak terawat dapat menjadi tempat berkembang biak dan peristirahatan nyamuk oleh sebab itu perlu dilakukan pengendalian dengan cara: a) Untuk mengurangi debu dapat dilakukan penghijauan. b) Melakukan kerja bakti membersihkan halaman sekolah secara berkala satu minggu sekali, c) Menghilangkan genangan air di halaman dengan cara menutup/mengurung genangan dengan pasir/kerikil, d) Melakukan pemangkasan secara berkala terhadap tanaman/tumbuhan yang ada di halaman sekolah dan e) Memasang pagar keliling yang kuat dan kokoh tetapi tetap memperhatikan aspek keindahan

\section{Kondisi Meja belajar bagi peserta didik}

Hasil pengamatan semua meja yang ada di SDN 13 Gasan tidak memiliki kemiringan $15 \%$ atau $10^{\circ}$ (datar)/ tidak memenuhi syarat, Meja yang tidak memenuhi syarat ergonomis dapat menyebakan ketegangan otot leher, bahu, dan punggung sehingga akan mengganggu konsentrasi belajar. Bila kejadian ini berlangsung bertahun-tahun dapat menimbulkan keluhan sakit kepala, nyeri leher dan punggung ${ }^{3}$ oleh sebab itu perlu dilakukan pengendalian dengan cara: pihak sekolah merencanakan dan mengusulkan pengadaan meja baru dengan Disain meja belajar memiliki kemiringan $15 \%\left(10^{\circ}\right)$ serta kursi bagi peserta didik disesuaikan dengan lama penggunaan dan perkembangan usia peserta didik.

\section{Prilaku}

Hasil pengamatan 82 siswa terdapat 38 orang siswa yang kuku panjang dan hitam (46\%) dan masih terlihat sampah berserakan dikelas. Kebiasaan yang dilakukan sehari-hari dapat mempengaruhi terjadinya penularan dan penyebaran penyakit. Sekolah merupakan tempat pembelajaran bagi peserta didik untuk membiasakan diri berperilaku hidup bersih dan sehat, untuk menurunkan penyakit risiko 
tertentu antara lain: buang sampah pada tempatnya, buang air besar di wc, tidak merokok, minum air yang telah dimasak, menjaga kebersihan diri (mandi, potong kuku, cuci tangan pakai sabun setelah buang air besar dan sebelum makan, menjaga kebersihan lingkungan ${ }^{5}$, oleh sebab itu perlu dilakukan upaya pengendalian faktor risiko dengan cara: a) Untuk mendorong peserta didik agar berperilaku hidup bersih dan sehat, diperlukan keteladanan dari pendidik misalnya tidak merokok di lingkungan sekolah, memiliki kuku yang pendek dan bersih, b) Membiasakan membuang sampah pada tempatnya dan menyediakan tempat sampah setiap ruangan, c) Membiasakan cuci tangan dengan sabun setelah buang air besar dan menulis dipapan tulih serta menyediakan tempat cuci tangan di depan kelas, d) Membiasakan memilih makanan jajanan yang sehat (makanan tertutup rapi, minuman tidak berwarna yang cerah/warna tekstil, dll), e) Melakukan pemeriksaan kebersihan dan secara berkala, antara lain: Kebersihan gigi, kuku, rambut dan telinga dan f) Memasang slogan, poster, stiker tentang menjaga kebersihan.

\section{KESIMPULAN}

Tingkat Risiko Kesehatan Lingkungan di SD N 13 Batang Gasan Kabupaten Padang Pariaman

\section{DAFTAR PUSTAKA}

1. Direktorat Jenderal PP dan PL. (2012). Pedoman Analisis Risiko Kesehatan Lingkungan (ARKL). Jakarta: Kementrian Kesehatan

2. Direktorat Bina Kesehatan Kerja dan Olahraga. (2012). Penyakit Akibat Kerja Karena Pajanan Logam Berat. Jakarta: Kementrian Kesehatan.

3. Direktorat Jenderal PP dan PL. (2014). Petunujuk Teknis Pengendalian Faktor Risiko Kesehatan Lingkungan Di Sekolah. Jakarta: Kementerian Kesehatan RI

4. Dinas Kesehatan Kabupaten Padang Pariaman. (2016). Profil kesehatan Kabupaten Padang Pariaman tahun 2016

5. Direktorat Kesehatan Lingkungan. (2016). Kesehatan Lingkungan Di Sekolah. Jakarta: Ditjen Kesehatan Masyarakat Kementerian Kesehatan RI adalah tinggi (65\%) oleh sebab itu perlu dilakukan upaya pengendalian faktor risiko

\section{SARAN}

1. Bagi Pihak Sekolah dan warga sekolah agar membentuk Tim pelaksana Usaha Kesehatan Sekolah. Menyediakan tempat sampah setiap ruangan, jamban untuk peserta didik, sumur gali/ Bor, Penyuluhan terhadap peserta didik untuk berprilaku hidup bersih dan sehat.

2. Pembina UKS/ Pihak Puskesmas/ Dinas Kesehatan agar memberikan penyuluhan terhadap Guru atau Pelaksanan UKS, melakukan penilaian sekolah 1 kali 6 bulan

3. Pemerintah Daerah/ Lintas Sektor atau Program agar memfasilitasi Kebutuhan SDN 13 Batang Gasan sesuai kebutuhan dan melakukan perencanaan, pembinaan, pengawasan dan penilaian terhadap pengendalian faktor risiko kesehatan lingkungan di sekolah

\section{UCAPAN TERIMA KASIH}

Ucapan terima kasih kami sampaikan kepada Direktur, UPT Penelitian, Ketua Jurusan Kesling Politeknik Kesehatan Kemenkes Padang yang telah Mensuport dan mendanai penelitian ini, Tim Peneliti dan Instruktur yang telah membantu sehingga penelitian ini dapat diselesaikan dengan baik dan tepat waktu.

6. Keputusan Menteri Kesehatan No. 1429/MENKES/SK/XII/2006 tentang Pedoman Penyelenggaraan Kesehatan Lingkungan Sekolah

7. Rahman, A. (2007). Public Health Assessment : Model Kajian Prediktif Dampak Lingkungan dan Aplikasinya untuk Manajemen Risiko Kesehatan. Depok: Pusat Kajian Kesehatan Lingkungan dan Industri FKM-UI.

8. Peraturan Menteri Kesehatan RI Nomor 32 tahun 2017 tentang Standar Baku Mutu Kesehatan

9. Lingkungan dan Persyaratan Kesehatan Air untuk Keperluan Higiene Sanitasi, Kolam Renang. Solus Per Aqua dan Pemendian Umum

10. SDN 13 Gasan. (2018). Profil Sekolah Dasar Negeri 13 Gasan. Kabupaten Padang Pariaman 